\title{
Editorial: \\ Nordic research on vocational education and training
}

\section{Per Andersson \& Sofia Nyström}

Linköping University, Sweden (per.andersson@liu.se, sofia.nystrom@liu.se)

Welcome to a new issue of the Nordic Journal of Vocational Education and Training. We continue to develop an open forum for research on vocational and professional education and training, with a particular focus on the Nordic contexts. Our journal is published online, open access, and there are no submission or article processing charges, which means that anyone with access to the Internet also has access to the research findings we present.

In this first issue of 2017 we publish articles in English, Norwegian, and Swedish. However, we continue to encourage publication of articles in English, which makes the audience of our authors' research findings much broader, but we still invite contributions in Danish, Norwegian, and Swedish too. Published research articles have undergone a double-blind peer-review by at least two anonymous reviewers. We also have a magazine section with other articles and information concerning vocational education, and the magazine articles are not subject to a double-blind peer review.

In relation to this issue we are also glad to inform you of the launch of the Nordic Journal of Vocational Education and Training Facebook page. On this page, you will find information about the new published articles and issues as well as other information that could be of interest.

\section{Five contributions}

In the present issue we have five articles, reporting studies from Finland, Norway, and Sweden. The first contribution is a magazine article from Finland. 
Promoting students' reflections in organisational improvisation arrangement between higher education and workplaces by Tiina Rautkorpi and Laura-Maija Hero. They discuss experimentation-based pedagogy in a Finnish university of applied sciences. This pedagogy means that multidisciplinary innovation projects are employed to improve students' skills.

The rest of the contributions are peer-reviewed articles. The second article, Lærings- og arbeidsvaner hos lærlinger (Learning and work habits among apprentices), by Per E. Garmannslund and Hilde Witsø. They study the use of an electronic monitoring tool to improve apprentices' learning and work habits and their professional awareness. According to their findings, the monitoring tool contributes positively to learning and work habits, and to apprentices' understanding of future professional responsibilities. The communication between apprentices and instructors is reinforced, as well as the reflection and effort among apprentices.

The third article is a study from Sweden, Health and social care teachers' descriptions of challenges in their teaching at upper secondary school by Eva Eliasson and Helena Rehn. They study how ideals concerning health care professionals' personalities and actions influence experienced challenges of teaching, such as lack of motivation, and low status of the occupation. The teachers construct categories of differences to understand and handle the challenges. Eliasson and Rehn highlight the importance of vocational education courses which put focus on the understanding of various norms and categorisations.

The fourth contribution is also from Sweden, a study concerning the professional identification among vocational teachers in the area of building and construction. In Lärare eller hantverkare? Om betydelsen av yrkeslärares yrkesidentifikation för vad de värderar som viktig kunskap på Bygg- och anläggningsprogrammet (Teacher or craftsman? The importance of vocational teachers' professional identification for what they regard as important knowledge in the Building and construction programme), Mattias Nylund and Björn Gudmundson examine the professional identification of vocational teachers' in building and construction in relation to what they see as important knowledge in their vocational programme in upper secondary school. They show that the professional identification is important for these teachers' identification of what is important vocational knowledge. Two types of teachers are identified: 'craftsmen' and 'teachers'. The 'craftsmen' primarily focus vocational knowledge, while the 'teachers' rather connect this knowledge with the pedagogical issues and the school culture.

The last article is another study from Norway. In Grunnleggende ferdigheter for arbeidslivet? Bruk og betydning i restaurant- og matfagyrker (Basic skills for working life? Use and importance in restaurant and food processing occupations), Halvor Spetalen puts focus on basic skills, defined as reading, numeracy, and oral, written and digital skills. The findings show that the use of basic skills in 
restaurant and food processing occupations is more common among managers and skilled professionals than among professionals without managerial responsibility, and non-skilled workers. This result provides valuable input to a coming reform in Norwegian vocational education and training.

We wish that these articles will give new insights and knowledge concerning different aspects of vocational education and training in the Nordic countries. For the future, we want to emphasize that our journal welcome contributions from all parts of the world, as long as the findings are of general interest and relevant also in relation to the Nordic contexts of vocational and professional learning, education, and training. 